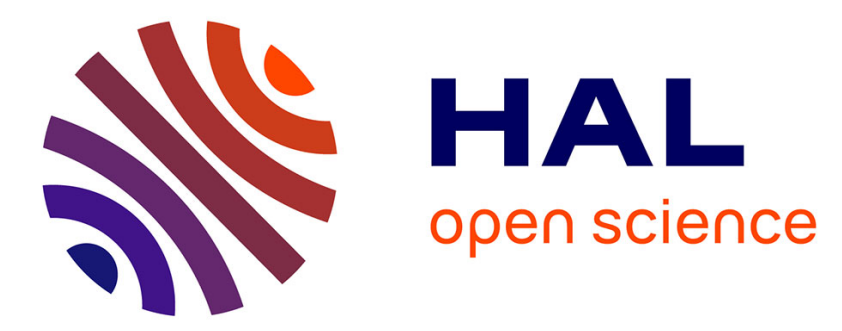

\title{
Towards a Bandung spirit-based civil society movement: reflection from Yogyakarta commemoration of Bandung Asian-African Conference
}

\author{
Darwis Khudori
}

\section{- To cite this version:}

Darwis Khudori. Towards a Bandung spirit-based civil society movement: reflection from Yogyakarta commemoration of Bandung Asian-African Conference. Inter-Asia Cultural Studies, 2006, Inter-Asia Cultural Studies, 7 (1), pp.121-138. 10.1080/14649370500463240 . hal-02570762

HAL Id: hal-02570762

https://hal.science/hal-02570762

Submitted on 20 May 2020

HAL is a multi-disciplinary open access archive for the deposit and dissemination of scientific research documents, whether they are published or not. The documents may come from teaching and research institutions in France or abroad, or from public or private research centers.
L'archive ouverte pluridisciplinaire HAL, est destinée au dépôt et à la diffusion de documents scientifiques de niveau recherche, publiés ou non, émanant des établissements d'enseignement et de recherche français ou étrangers, des laboratoires publics ou privés. 


\title{
Towards a Bandung spirit-based civil society movement: reflection from Yogyakarta commemoration of Bandung Asian-African Conference
}

\section{Darwis KHUDORI}

\begin{abstract}
This article deals with a commemoration of the 50th anniversary of the Bandung AsianAfrican Conference 1955. Held in a modest way, in Yogyakarta, Bandung and Bangkok, the commemoration leaves, a durable contribution: the conference book - an anthology of reflections related to this world historical event. Written by 16 socially engaged intellectuals, academics and activists from Africa, Asia, Latin America, Europe, and USA, the book is entitled 'BANDUNG 2005: Rethinking Solidarity in Global Society. The Challenge of Globalisation for Social and Solidarity Movements.' The objective of the work is to look for alternatives to the present undesirable World Order and Globalisation. Put in the perspective of social history (of social struggle, social movement, or social change), the Yogyakarta Commemoration of the Bandung Asian-African Conference deserves close attention. The actors involved in the publication and in the meeting, the messages they delivered and the projects they proposed, are too important to be ignored. This article presents an analytical review on the commemoration, especially on the content of the book, completed by a concluding remark on the prospect of the movement.
\end{abstract}

KEYWORDS: Asia-Africa, Bandung spirit, civil society, globalisation

\section{Introduction}

The 50th anniversary of the Bandung AsianAfrican Conference 1955 (BAAC) deserves solemn commemoration. There is no doubt about it. There is no need to repeat here the importance of BAAC in world history. What is interesting to notice is the multiplication of commemorations, mainly by civil society movements. While the government of Asian and African countries have united their forces to organise a unique commemoration in Jakarta and Bandung, transnational civil society movements have given birth to diverse initiatives of commemoration in all over the world in 2005 (Porto Alegre, Cairo, Bandung, Yogyakarta, Jakarta, Bangkok, Kerala, Colombo, Tokyo, ...).

This article deals with one of the commemorations, which was held in a modest way in Yogyakarta, Bandung and
Bangkok, but which leaves a durable contribution: the launch of a conference book, an anthology of reflections related to the 50th anniversary of Bandung AsianAfrican Conference 1955. Written by 16 socially engaged intellectuals, academics and activists from Africa, Asia, Latin America, Europe, and USA, the book is entitled 'BANDUNG 2005: Rethinking Solidarity in Global Society. The Challenge of Globalisation for Social and Solidarity Movements' (Khudori 2005). It is based on a common concern that

\footnotetext{
Now, 50 years later, colonisation has officially disappeared, the Cold War has ended, the Non-Aligned Movement has almost lost its reason of being. Humankind has entered into a new era of civilisation generated by the Information and Communication Technologies (ICTs): Globalisation. Yet, similar systems of domination by the powerful
} 
in the world order persist, wars continue to threaten humanity and injustice has appeared in more sophisticated forms and larger dimensions. Where is our world going? Is a better world still possible? Is there any alternative to the present course of globalisation?

(Khudori 2005: x)

The words ' 50 years later' refer to the Bandung Spirit expressed in 1955 by the African and Asian Countries, which can be summarised as 'a call for peaceful coexistence, for independence from the hegemony of any superpower and for the creation of solidarities related to disadvantaged peoples.' (Khudori 2005: ix). The objective of the work is to look for alternatives to the present undesirable World Order and Globalisation.

Put in the perspective of social history (of social struggle, social movement, or social change), the Yogyakarta Commemoration of the Bandung Asian-African Conference deserves close attention. The actors involved in the publication and in the meeting, the messages they delivered and the projects they proposed, are too important to be ignored. An analytical review on the commemoration, especially on the content of the book, would be useful for the enrichment of social sciences, but also for the improvement of social movement in general and for the follow-up of the event itself in particular.

If we accept the rough definition of Social Movement, which is a collective effort aimed at either changing or preserving some aspects of a social system, the working group involved in Yogyakarta Commemoration raises a question of whether it can be identified or analysed as a social movement. If yes, what is its prospect?

To answer those questions, the classical work of Alain Touraine, which identified a social movement according to three principles: identity, opposition, and totality, ${ }^{1}$ can be useful. Based on these principles, the characteristics of the Yogyakarta Working Group can be identified through the following questions. Who are they? What is their identity or what is the common reference of their actions? Who is their adversary? What is the point of their opposition? What kind of situation do they criticize? What alternatives do they propose? What is their concept of World Order? What kind of change do they wish to introduce? How do they translate their concept into reality? What is their project? What programmes and actions do they put into their agenda?

Those are the questions guiding the direction of this article.

\section{International networks for alternatives}

The actors involved in the Yogyakarta Commemoration did not get together by chance. They have progressively formed a working group, over more than a year, for the commemoration of BAAC. Seen from their involvement in the Yogyakarta Commemoration, they can be distinguished into several groups: the Steering Committee members, the authors, the speakers, the Organising Committee members, the simple participants of the conference,... Not all the Steering Committee members participate in the book and not all the authors belong to the Steering Committee. Not all the authors were present in the conference and not all the speakers of the conference are authors of the book. For the sake of reliability, this article concerns only the authors of the book. They came from five sources more or less internationally known for their work on alternatives to globalisation.

First, the networks of TWF (Third World Forum), CETRI (Centre Tricontinental) and WFA (World Forum for Alternative) led by Samir Amin and François Houtart. There are two authors and two collectives from this network: Bernard Founou-Tchuigoua (Cameroon/Senegal), Nirmal Kumar Chandra (India), AAPSO (Afro-Asian People's Solidarity Organization, Egypt), and AIPSO (All India Peace and Solidarity Organisation, India).

Second, the network of SEIN (Socially Engaged Interfaith Network) led by spiritual and religious thinkers and leaders such as Sulak Sivaraksa, Chandra Muzaffar, Abdurrahman Wahid, and Wolfgang R. 
Schmidt. Two authors came from this network: Majid Tehranian (Iran/USA) and Wolfgang R. Schmidt (Germany).

Third, the network of the Nagoya Workshop (on Spirituality-based Social Movements facing Globalisation) initiated and coordinated by Darwis Khudori. This network is represented by eight authors: Bernadette Andreosso-O'Callaghan (France/Ireland), Darwis Khudori (Indonesia/France), Jean-Pascal Bassino (France/ Japan), John Lannon (Ireland), Kaarina Kailo (Finland), Parichart Suwanbubbha (Thailand), Patricia Morales (Argentina/ Netherlands) and Yukio Kamino (Japan).

Fourth, the network of the Centre International Lebret-IRFED (International Network for Dialogue and Development) led by Sergio Regazzoni and Yves Berthelot. This network contributed two authors: Boutros Labaki (Lebanon/Italy) and Yves Berthelot (France).

Fifth, the independent source. Two authors were invited to join in the publication for special reason. The first is Hersri Setiawan (Netherlands/Indonesia) for his testimony as an actor of BAAC and of the cultural policy set up by the 'Bandung Countries'. The other is Pierre Rousset (France) for his role in WSF (World Social Forum).

\section{Bandung Spirit}

Although the authors work together in the framework of commemoration of BAAC, not all of them evoke the relevance of the Bandung Spirit for the present era of Globalisation in their essays. This is understandable since the relevance seems evident and the collective work is oriented toward an alternative instead of a review of the past. Some of them however do evoke the Bandung Spirit. In general, the Bandung Spirit is associated with the struggle against the domination by the powerful over the weak in the world order, a fact denounced by BAAC 1955 that continues to function today.

For Hersri Setiawan, ${ }^{2}$ for example, economic globalisation at present is nothing else than a new form of capitalism (Setiawan 2005: 8). For him, the Bandung Spirit is the spirit of anti-capitalism. 'In order to establish the bastion of defence required in resisting the domination of foreign and global capital, national sovereignty must be strengthened. The Flame of Bandung is actually still burning. How to re-ignite the flame is the question we are now facing' (Setiawan 2005: 12).

Some essays notice that the conditions denounced by the Bandung leaders in 1955 continue to exist today. AIPSO, for example, quotes Sukarno who warned in his speech: 'I beg of you do not think of colonialism only in the classic form.... Colonialism has also its modern dress, in the form of economic control, intellectual control, actual physical control by a small and alien community within a nation. It is a skilful and determined enemy, and it appears in many guises .... Wherever, whenever and however it appears, colonialism is an evil thing, which must be eradicated from the earth' (AIPSO 2005: 14-15). This, according to AIPSO, is a prescient description of neocolonialism, and would accurately describe the occupation in Iraq and Palestine (AIPSO 2005: 15). Another point related to colonialism is the ideological imposition denounced by Nehru as 'most degrading and humiliating to any self-respecting people or nation' (AIPSO 2005: 16). Today, AIPSO notices, ideological impositions ranging from particular Western-oriented notions of democracy and human rights to neo-liberal economic reform are widespread and so are ideological justifications for illegal international acts ranging from the invasion of Afghanistan, the occupation of Iraq and Palestine, and the threats against Syria and Iran, to cite just a few instances (AIPSO 2005: 16).

For AIPSO, Bandung is significant today because its core concerns remain and, in the absence of a countervailing political bloc in the form of the erstwhile socialist bloc, are if anything more important. Neo-colonialism is a major threat. The flagrant US-backed attempt to overthrow President Hugo Chavez of Venezuela is just a recent example. This is based on a strident ideological 
campaign based on an unprecedented control over the global media. This campaign is simply the imposition of 'American values' or rather those of a section of the US power elite (AIPSO 2005: 16). 'In these times there is much more that can be said about such a bold and sweeping effort to reorder the world as was attempted with such success starting in Bandung in April 1955. The world has changed, so have the challenges. But the basic hopes and urges of our people have not. We owe a lot to Bandung. Most of all we owe our people the commitment and courage to carry forward the unfinished tasks, so that our freedom will flourish in peace and plenty' (AIPSO 2005: 20).

\section{Challenge: world order and globalisation}

Since the beginning of its formation, the Yogyakarta Commemoration Group has stated the present World Order and Globalisation as the subjects of criticism. The authors of BANDUNG 2005 present their criticisms in different ways, ranging from cool academic notice to strong denunciation typical of militant activists. Among the first category, we found, for example, the essay of Bernadette Andreosso-O'Callaghan ${ }^{3}$ and Jean-Pascal Bassino $^{4}$ who studied the socio-economic evolution of 'Bandung' Asian-African countries from 1960 to 1999. They concluded that:

First, the 'Bandung' African countries were relatively richer than the 'Bandung' Asian countries in 1960. Second, economic growth has generally tended to be much more vigorous over the 1960-1998 period in Asia than in Africa. This has developed into a widening gap between Asian and African countries over the period, with Asian countries quasi systematically outperforming their African counterparts. Third, the divergence between Asia and Africa can be seen in terms of both economic and human development indicators. These results are undoubtedly the greatest drawback of modern economic development, and a proof that some of the objectives of the Bandung Declaration failed to materialize. (Andreosso-O'Callaghan and Bassino 2005: 48)
A strong denunciation can be found, for example, in the essay of Kaarina Kailo, ${ }^{5}$ who wrote that

This is a moment in history when we are witnessing the highway robbery of humanity's and womanity's collective heritage, the treasures and gifts of women, of the land, of nature, of indigenous people - gifts which are increasingly taken or harnessed to serve the market and the small elite controlling and owning the world's freely mobile capital... I believe that we now live in a climate of popular apathy, frustration, even indifference, and most surprising and threatening of all - in a climate also of surprisingly wide-spread acceptance of the corporate take-over of the commons. (Kailo 2005: 73)

The criticisms can be classified into three levels, from the most concrete to the most abstract ones: Politico-economy, Model of Development and World View.

\section{Politico-economy}

The most concrete criticisms deal mainly with politico-economy. AIPSO denounces strongly the domination of the rich countries in the world order.

Backed by the troika of the World BankIMF-WTO, the G-7 countries headed by the US are trying to impose a particular economic model on other countries throughout the world in the name of neo-liberal economic reform. ... Decisions to privatize public holdings, deregulate the economy, and reduce labour rights are not just 'economic' decisions but are profoundly political. Likewise as the UNDP Human Development Reports and other documents have shown, these so-called reforms have aggravated existing inequalities, and led to a transfer of wealth from the poor and middle classes to the rich. The gap between the top $20 \%$ and the bottom $20 \%$ in the world has increased from 30:1 in 1960 to over 92:1 now. (AIPSO 2005: 16-17)

On the same basis, Nirmal Kumar Chandra ${ }^{6}$ wrote: 'Globalisation as conceived 
by the Washington Consensus, primarily the US Treasury, acting in concert with US finance capital (Wall Street), US-based transnational corporations and consultants, and implemented by the multilateral institutions like the IMF, the World Bank and the WTO, seeks to reverse the process of de-colonialisation that started after World War II...' (Chandra 2005: 29) and

\begin{abstract}
Agricultural trade illustrates some of the glaring inequities of contemporary globalisation. By providing huge subsidies, the rich countries drive down the world market prices, accentuating poverty in the developing countries, while enriching a handful of prosperous farmers and giant domestic companies. Thanks to its cotton subsidy, the US control $40 \%$ of global trade; that deprives West Africa of $\$ 200$ million in export revenue and pushes the region deeper into external debt. For the Third World as a whole, it is estimated that agricultural exports would have gone up by two-thirds from the current level of $\$ 36$ billion. Of the total US farm subsidies of $\$ 17$ billion in 2001 , only $12 \%$ went to the bottom $80 \%$ of farms, while as much as $\$ 12.4$ billion went to the top $10 \%$, including several Fortune 500 companies and billionaires like David Rockefeller, Ted Turner and so on. Furthermore, unlike manufactures, rich countries pegged the import tariff on agricultural goods at a high level so that consumers often pay much higher prices than in developing countries. All this leads to a deadweight loss for the vast majority of mankind in both developing and industrial countries far outweighing the bonanza for the super rich in the West. (Chandra in Khudori 2005: 34)
\end{abstract}

\section{Model of development}

The criticisms on the model of development can be found in the essay of Yves Berthelot. ${ }^{7}$ He wrote, for example,

Fifty years later, rather than criticising globalisation for its weak theoretical basis the neo-liberal agenda updated - and its failure to reduce gaps between rich and poor, it is more forward-looking to question the socio-economic model that globalisation imposes in the mind of politicians and wishes of the consumers. The time has come to ponder on the necessary changes in the behaviours of consumers and producers. The fashionable expression of 'sustainable development' has led so far to rules, too often left in books and to a few corrective actions, but not to a change of model. The present model is unsustainable as it destroys both the environment and the social fabric. Conducted by enterprises with the dominant objective of short-term maximisation of the value of stocks and by governments striving for GDP growth, economic activities neglect the creation of jobs or develop 'undecent' conditions of work. They are now threatening the future of our children more than they are building it. It is indeed admitted that if all developing countries, and first of all those of Asia, were to enjoy the pattern of consumption of the United States or Europe, the pressure on natural resources, including air and water, would be unsustainable. This is difficult to say, as it could be interpreted as denying other people the right to enjoy OECD standards. But, it means simply that the OECD model is not adapted to present circumstances: therefore, people from OECD countries will have to change their way of life and people from other parts of the world will have to change their implicit model. We still all equate more to better, when in fact more threatens the future. This, also, is particularly difficult to say when so many people are suffering hunger and cannot benefit from their human right to 'adequate conditions of living'. But, hunger is not caused by the shortage of food but by trade mechanisms: the world food production exceeded nutrition needs by $23 \%$ in 2000, and market forces conduct to invent needs for the wealthy and to neglect basic needs and services for the poor. (Berthelot 2005: 52-53)

\section{Worldview}

At the level of Worldview, we found criticisms; for example, in the essay of Kaarina Kailo. For her, the situation, as she 
denounced above, is deep-rooted in the 'dominant Western paradigm and worldview', which she calls 'Master Imaginary'.

Echoing aspects of self-interest and non-giving of the exchange economy (Vaughan 1997), the concept condenses the artificial and arbitrary dichotomies that have allowed white heterosexual elite men to dominate nature, women, native populations and people of colour as well as men defying the hegemonic gender contracts. Among the central elements of the master imaginary are assumptions and projections of nonegalitarian difference (e.g. humans vs. animals, primitives vs. the civilised, mind vs. matter or spirit) which, upon closer scrutiny are merely ideological tools of control; tools through which the dominant hegemonic class has sought to control, subjugate and label those it has placed in the periphery of its hierarchical order. Women can and do, at different locations of power and privilege embrace this world-view and its logic of mastery over the entities defined as 'other.' Among subjugated or exploited peoples, we are currently also witnessing the emergence of an internal elite that is willing to sell out to the market forces, even when its worst excesses mean deepening inequities and an ecologically unsustainable future. Although whites, non-whites, men and women can embrace this economistic imaginary, its roots are in the asymmetrical sex/gender systems of honour-based patriarchies and thus contain gendered and gendering processes. In its dysfunctional core, honour consists of safe-guarding maleoriented sexual, religious and property 'rights,' even when it can mean engaging in the shameful phenomenon of gender-based control - 'honour murders' - by members of certain patriarchal societies. (Kailo 2005: 75-76)

At the same level, Yukio Kamino ${ }^{8}$ states that the present environmental crisis is deep-rooted in the dominating worldview identified in three mutually overlapping components: materialism, narrow selfconcept and generationalism.
Materialism or the obsessive interest in obtaining material goods, including those that lack real merits or which are even harmful, stems from the uniquely human capacity to create our own perception of needs apart from those that are genuine. Materialism is prevalent at this period of neo-liberal globalization, where 'the Market is becoming the first truly world religion,' if religion means 'what grounds us by teaching us what world is, and what our role in that world is' (Loy 2000, 15) ... This frantic consumerism is tragic on multiple levels. It is a grave challenge against the principle of sustainability because the ecological footprint (i.e. human pressure on the global ecosystem) varies enormously according to lifestyle (e.g. in energy consumption, an average US citizen equals 140 Bangladeshi citizens). Moreover, four to eight Earths would be needed if the entire human race were to live like the wealthiest $20 \%$ do (Botkin \& Keller 2005, 68; Davison 2004, 133) .... The disadvantage of materialism for personal life is also that of narrow selfconcept: once basic needs are satisfied, happiness requires psychological fulfilment through caring social relations based on the mutual transcendence of 'I-others' dichotomy. Environmental sustainability, in addition, requires the transcendence of (one level higher) 'wethey' dichotomy, because selfish communalism negatively directed at the outside world is unlikely to fulfil the universal environmental responsibility. Moreover, group solidarity representing the 'we vs. they' mindset may even become the social basis for military conflict - a nightmare for both environmentalists and pacifists alike. Finally, the transcendence of narrow selfconcept also involves that of the 'human-nature' dichotomy, particularly associated with the Western civilisation and infamous among environmentalists.... Finally, the worldview for 'ecotopia' also transcends the third bias or limitation of generationalism, or a tempo-centric perspective focused on the consideration of welfare for the current set of generations. 
Whereas the prevalent paradigms today are based on unarticulated and virtually unrecognized tempo-centric assumptions, 'the obligations of the ecological citizen extend through time as well as space, towards generations yet to be born (Dobson 2003, 106). (Kamino 2005: 103-105)

\section{Response: goals, areas and issues}

The responses can be ordered into three levels: goals, areas, issues.

\section{Goals: global solidarity in a plural world}

We qualify goals as the farthest points to be reached among all the points proposed by the authors. They are found mainly in the essay of Majid Tehranian ${ }^{9}$ and Wolfgang R. Schmidt. ${ }^{10}$ It is based on a conception of world order, which perceives human civilization 'not in terms of stages a la Marx, Rostow or Bell, nor as cycles of birth, development and death a la Spengler, Toynbee or Sarkar' (Tehranian and Schmidt 2005: 152). The authors view civilization as a layering process from nomadic to agrarian, commercial, industrial and digital (Tehranian 2005). The World community is today deeply divided among these five modes both within and among nations. The wars in Afghanistan and Iraq cannot be fully understood until we view them as a conflict between different modes of civilization. More than two-thirds of the world today lives in the pre-industrial mode, reflected by $\$ 2$ a day of income. The growing economic, political, and cultural disparities between the five modes suggest a possible global civil war of states and opposition terrorism without physical and moral boundaries for an unknown period of time (Tehranian and Schmidt 2005: 152).

The coexistence of the five layers of human civilisation, combined with identity, commodity and security fetishisms have created a world of antagonisms between differing layers of mechanic solidarities. For that reason, a Global Solidarity is needed, a
Global Solidarity that has to anticipate the life interest of all and therefore to be in solidarity with in-equals, including the 'other', the 'foreigner', the 'they' and the 'we', everyone who lives in any of the five layers of human civilisation. The authors call this solidarity 'An Organic Human and Global Solidarity for Life', because this kind of solidarity takes into account not just one aspect, one person's or group's view, one area of interest or one source of power. But it takes into account everything organically and pertaining to life: diversity with respect to cultural, social, ethnic and national matters and gender differences (Tehranian and Schmidt 2005: 153).

In order to achieve this goal, a Global Civil Society Movement is needed. Why? Because, among the four stakeholders of the World Order (States, Markets, Civil Societies, Communication Networks), the Global Civil Society constitutes the most sympathetic one (Tehranian and Schmidt 2005: 155). It is in this scenario that 'Bandung $I I^{\prime}$ (the term proposed by the authors for a movement related to the 50th anniversary of the Bandung Asian-African Conference) can play an important role. It can be charged with a mission of promoting Global Solidarity in a Plural World consisting of three elements:

(1) Bandung II can unite the emerging Global Civil Society from all five civilisations into a coherent political voice to counter the hegemonic strategies of the global economic and political forces.

(2) Bandung II can establish a growing network of global economic, political, and cultural networks for human security and dignity, sustainable development, and the pursuit of a world peace with peaceful means.

(3) Bandung II can mobilise the considerable cultural resources of an emerging global society to produce a new global civilisation based on unity in diversity (Tehranian and Schmidt 2005: 154).

A set of goals of the movement is proposed: 
- Maintenance of Human unity in diversity.

- Human civilisation as a common journey in pursuit of peace with peaceful means.

- Human dignity and security as the first and foremost common goal of human civilisation.

- Respect for sovereignty at all layers of human society, from tribes to villages, cities, states, regions, and the Planet Earth.

- Respect for the interdependence of human civilisation and its natural environment.

- Concrete measures to narrow the gaps among the five modes of human civilisation by means of transfers of knowledge, science, technology, capital, and management.

- Mobilisation of the Global Civil Society to persuade the Global Market, State, and Communication Network to work toward the above common goals (Tehranian and Schmidt 2005: 157).

More concretely, the movement has to develop policies to deal with the following strategic objectives:

- Democratising global governance.

- Democratising national governance.

- Promotion of women's participation in all aspects of society.

- Respect for the rights and sovereignties of repressed minorities or majorities.

- Micro credit for all layers of human entrepreneurship.

- Reforming and strengthening of the United Nations system.

- Freedom for the mobility of labour and capital across national boundaries.

- Establishment of a world currency pegged to all other national currencies.

- United Nations citizenship for all those requesting it.

- Outlawing of all forms of violence, from domestic to international.

- Reform of the current global juridical systems to bring all violators to justice.

- Establishment of several global funds to encourage innovations in science, technology, and arts.

- Taxation of global commons such as the electromagnetic spectrum, geostationary orbit, ocean resources, or currency exchanges to finance the global funds (Tehranian and Schmidt 2005: 158).

\section{Areas and issues}

Not all the articles propose issues to be worked out in the future meetings. Some of them are meaningful in giving input instead of raising issues: the work of Hersri Setiawan (on the historical background and testimony to BAAC 1955), Patricia Morales ${ }^{11}$ (on the notions of solidarity in the constitutions of Latin American countries), Pierre Rousset ${ }^{12}$ (on the evolution of World Social Forum), and AAPSO (on the summary of Cairo Conference related to the Commemoration of BAAC 1955). Those proposing issues can be grouped into six areas previously planned: Politics, Economics, Culture, Environment, Education and Communication.

\section{Politics: economic reform, democratisation of UN, peace movement}

Issues in Politics are proposed mainly by the essays of AIPSO and Bernard FounouTchuigoua. ${ }^{13}$ Both essays denounce the continuous domination by the powerful in the World Order. AIPSO speaks about the 'neo-colonialism' led by the USA, as quoted previously, while Bernard Founou-Tchuigoua speaks about the 'collective imperialism' begun by the intervention of the USA to compel France and the UK to put an end to the war against Egypt following the nationalisation of the Suez Canal in 1956.

Both essays also evoke the use of social sciences for the interest of the powerful: 'ideologication of education especially in Humanities and Social Sciences' (AIPSO 2005: 17) and 'instrumentalisation of social sciences' (Founou-Tchuigoua 2005: 24).

At the level of proposal, AIPSO put forward three issues: Economic Reform, Promotion of Peace, and Democratisation of the UN. 'For us, to build alternative models to this disastrous one, an economic solidarity is a must. Economic ties including exchange of technologies, scientists, experts, capital and trade flows should be matched 
by exchange of experiences about alternative, more equitable, self-reliant paths of economic development. Southern-based regional economic alliances, which are genuinely independent and not penetrated by the US and its allies, are indispensable. So are efforts to set up regional banks and financial institutions that would act as an alternative to the World Bank and IMF. This would require considerable political will, but there otherwise would be no alternative to US-led Northern economic domination, and the ultimate economic dependence of most of the South' (AIPSO 2005: 17-18).

On Peace, AIPSO wrote:

Most pressing is the issue of peace. Under the guise of proliferation of WMDs, Iraq was invaded and occupied, even though WMDs have never been found there, before or after the occupation. Iraq and North Korea [DPRK] are being threatened by the US now. There is a blatant hypocrisy at work. The Israeli nuclear technologist Mordechai Vanunu exposed the Israeli nuclear program nearly a couple of decades ago. But despite the fact that it has a massive nuclear arsenal, an atrocious human rights record including the practice of apartheid-type policies against Palestinians, and the systematic violation of UN Security Council resolutions, there has been virtually no action against it. Instead, it has been rewarded despite its apartheid and colonisation. India and other countries of the South argued during the formulation of the NPT, that there should be safeguards against both horizontal and vertical proliferation. Countries should not be permitted to develop new generations of nuclear weapons, i.e. indulge in vertical proliferation. In stark contrast, the US is trying to develop WMDs in space the so-called 'son of Star Wars' program. (AIPSO 2005: 18-19)

\section{For that respect, AIPSO proposes}

building a strong peace movement backed by and responded to by the states of the South and their allies. Organically linking this peace movement to those in the North as well as building a similar worldwide civil society-state alliance for a law governed egalitarian order in which politico-ideological and military intervention in the internal affairs of states are banned. To achieve this, not only will the Bandung agenda have to be amplified to meet the new challenges. But a basic political and social task that was earlier neglected will have to be given pride of place. Fifty years ahead in independent democratic existence, the politics of the countries of the South has irrevocably changed. Now these countries, on the whole, have thriving, vibrant civil societies. The new agenda will not be confined to states. It will also have to be based on the needs and urges of civil society. This will make the whole revival of the Bandung spirit both more meaningful and powerful. For instance, where states resist as in the US and UK over the occupation of Iraq, the interaction between civil societies in the US and UK, and the rest of the world may have a crucial impact and prove in time to be a corrective to an unyielding government. (AIPSO 2005: 19-20)

Economics: Africa, economic policy and socioeconomic model of development

The essays dealing with economic issues evoke several points, as mentioned in the Politico-economy section above: the weakness of Africa (Bernadette AndreossoO'Callaghan and Jean-Pascal Bassino), the domination of the US and its allies in economic globalisation (Nirmal Kumar Chandra), and the model of socio-economic development (Yves Berthelot). The issues proposed are clear: Empowerment of Africa, Reform of Economic Policy, Change of Socio-economic Model of Development. However, the means for reaching these objectives are diverse.

For Bernadette Andreosso-O'Callaghan and Jean-Pascal Bassino, 'the risk of increased socio-economic isolation of the African continent for the decades to come can be halted by the deeper and more systematic involvement of civil society (NGOs in particular) in these countries' (AndreossoO'Callaghan and Bassino 2005: 49). 
For Nirmal Kumar Chandra, 'For an alternative world, it is important that the rules of the game in trade, investment and capital flows are drastically changed. The Bandung spirit must be revived. Major developing countries like China, Indonesia, India, South Africa, Mexico and Brazil have to collaborate not just to promote their narrow 'national' interests but to leave space for other Third World countries to develop in a fair and equitable manner' (Chandra 2005: 38).

For Yves Berthelot, 'Regionalism' could help to change the model he criticised. It is based on the fact that 'contrary to what could be expected, that the external trade of the broad regions of the world evolved towards a much closer integration of the countries within each region rather than towards a global engagement. Statistics show, also, that the more a region is industrialised, the more important is its intra regional trade. The regional trade concentration has been a long-standing phenomenon in Western Europe. The same phenomenon occurred in Latin America and Asia with the diversification of their economies. For Africa and the Middle East, the very low level of regional integration reflects the countries' continuing dependence on a few commodities exported throughout the world and their low level of industrialisation' (Berthelot 2005: 54). 'But for regionalism to become a strong movement, it is still in need of proper practices, clear goals, and concrete results. At the regional and interregional levels, dialogues have to be transformed into negotiations of agreements, imbalances between parties have to find compensations and regional views have to impact effectively on global negotiations. If regionalism succeeds, it will have a decisive influence on the management of globalisation and the evolution of ideas' (Berthelot 2005: 57-58).

For that respect, the role of CSOs (Civil Society Organisations) is very important, especially to 'ensure that people recognise the necessity to change the model and participate in the emergence of social organisations that respect their culture and meet their needs' and 'that regional entities conduct internal and external policies for the people and that national policies aim at meeting basic human needs for today and tomorrow' (Berthelot 2005: 58).

\section{Culture: identity, religion, gender}

Three issues are proposed in the area of culture.

The first, proposed by Darwis Khudori, ${ }^{14}$ is social movements based on identities (religion, ethnicity, gender, territoriality) as a potential leading actor for finding alternatives to the present course of globalisation. This is because, since the end of the 20th century, the identity-based social movements have taken an increasingly important role among the existing social movements in challenging the present World Order. Different from the social movements of the industrial era (mainly trade-unionism), which are essentially based on the same logic of their adversary (economic well being), the identity-based social movements of the globalisation era propose a world order based on a completely different logic: the development of the 'self', of the 'meaning', of the 'sense', for which identity is the main source (Khudori 2005: 60-71).

The second, proposed by Boutros Labaki, $^{15}$ is inter-religious dialogues, especially focused on the question of 'development' and 'underdevelopment' as the necessary part of the collective work. This concerns especially the Christians and the Muslims in the context of an unequal relationship between the North (developed, industrialised, rich countries) and the South (developing or less developed, poor countries), where the North is deeply attached to Christianity while the South is largely populated by the Muslims (Labaki 2005: 84-98).

The third is the need to change the dominant worldview based on which the neo-liberal globalisation operates. Kaarina Kailo names this dominant worldview 'Master Imaginary' as described in her criticism above. This is to be replaced with what Kaarina Kailo calls 'Gift Imaginary', which 
'has at its core the undoing, the dismantling, the blurring of the arbitrary, unjust dualisms within the master imaginary. It refers to another sensibility and ethos than the binary logic and hierarchical dualisms of the master imaginary. We cannot have the abundance needed for gift giving and the provision of basic health, food and security in a situation of artificial scarcity, created through wars and economic arrangements set up to benefit the few at the expense of the many. Yet, capitalism - particularly in its hypercompetitive and crude form under neoliberal globalism - is based on the kind of capital accumulation and artificial, economically created scarcity that cannot but lead to deepening human tragedies of poverty and need' (Kailo 2005: 76). For that respect, Women's Movements play an important role. 'Women from around the world have stressed in their culture-specific ways that we need nothing less than a radically other world view, one based on a recognition of the collusion of patriarchy and male hegemonies with the systems based on undemocratic structures allowing the most vulnerable groups - women, children, ethnic minorities - to be abused and exploited. Instead of a common consumer culture unifying all people in a shared quest for material gratification, we feel the competitive masculated model (with which women too are now beginning to identify) must be replaced by the gift logic, the ancient and to some extent continuing practices of gift circulation. Otherwise, we cannot re-introduce loyalties to place and community - the bedrock of ecological and social sustainability' (Kailo 2005: 80-81).

\section{Environment: sustainable future}

Facing the global environmental crisis, the only essay of the book focused on te environment, by Yukio Kamino, stresses the need to secure a sustainable future.

The essay identifies that the environmental crisis, like economic globalisation, is 'historically connected to the Industrial Revolution that marked the transition from a solar economy to a "carbon economy," explosive population growth, the spread of "Western civilization" over the rest of the world, etc. Finally, most studies on the relationship between today's environmental crisis and economic globalization indicate that the latter has undermined Earth's ecological integrity through a variety of processes' (Kamino 2005: 101-102).

The essay focuses on the identification of the fundamental cause of the environmental crisis: the dominating worldview of today as he described in his criticism above. He proposes to replace this worldview by an alternative paradigm suitable for sustainable development. The question is 'how can we possibly promote such a paradigmatic transformation among humanity?' This task demands the committed dedication and close collaboration of a diverse cast of social actors. The nation-states can still play an important role as demonstrated in the application of Kyoto Protocol. In the private business domain, many corporations in various industries are investing to promote new technologies that are substantially more eco-efficient than those of today. 'Yet, it is logical to presume that the public and private sectors - the two traditional domains that have led humanity to this ecological crisis - are by themselves incapable of shouldering this historic transformation in civilisation. There must also be a significantly enhanced contribution from the third non-governmental and non-profit sector that has been making impressive advances lately' (Kamino 2005: 106).

\section{Education: human dignity, pluralism, dialogue}

Several issues are proposed by Parichart Suwanbubbha ${ }^{16}$ in her essay dealing with education.

The fundamental one is the need to preserve 'Human Dignity' as the most important value of human beings. This is to anticipate the consequence of globalisation that views and treats people like objects (Suwanbubbha in Khudori 2005: 112).

The second issue evoked by the essay is 'Pluralism', because globalisation has also connected people and the world together. 
'Many languages, cultures and religions imply both similarities and differences. As a result of differences, it is necessary to prepare our young generation to cope with the differences of others' (Suwanbubbha 2005: 113).

Related to Pluralism, 'Dialogue' came as the following issue to be promoted as a part of pedagogical activities. 'In this way, people may learn more effectively about autonomous differences of cultures, religious belief and the standpoint of others.' Moreover, 'Through the process of dialogue, conflict and violence could be reduced as dialogue enables people to listen to the reasoning of others that may otherwise never been known or understood. Furthermore, cross-cultural empowerment may occur. Above all, dialogue is transferred into action when people put the problem at the center and each partner in dialogue contributes by sharing their ideas about the solution from their standpoint or from those of each religious and cultural belief' (Suwanbubbha 2005: 114).

In the spirit of preserving Human Dignity, the underprivileged people have to be included in education. In that respect, informal and non-formal educations are to be developed as a bridge between formal educational functions and publicly influential educational performance. In the same spirit, community has to be considered also as a source of learning, especially regarding the existence of 'local wisdom'. Community has to be seen not as a static place, but a place composed of 'a group of people who share the same objectives and values. People in a community create solidarity, mutual communication, care, respect, tolerance, friendship, sharing in the process of learning and a natural and moral leader with good administration and management' (Suwanbubbha 2005: 116).

\section{Communication: ICTs (Information and Communication Technologies)}

In the area of communication, the only essay on this subject, written by John
Lannon, ${ }^{17}$ evokes the challenge of Globalisation for Social and Solidarity Movements in the field of ICTs (Information and Communication Technologies). 'The challenges of globalisation for social movements lie in finding ways to dialogue and communicate with communities around the world, to discover how globalisation is affecting us all, and to begin forming global solidarities to deal with the negative consequences. Information and communications technologies present them with an opportunity to tackle these challenges, and to build themselves a platform upon which to collaborate, mobilise, observe, and publish' (Lannon 2005: 128).

One of the most pressing ICT-related challenges for social movements is appropriation. 'Few social movements have ideological or moral difficulties using ICTs, but many are struggling with the issue of how to mould these globalising tools for their needs, and how to use them strategically and creatively for the benefit of all. It is critical for them that ICT policy and procedural issues - such as Internet governance - do not simply reflect the dominant globalising discourse(s), but that they are open to all interests. Social movements are not interested in controlling the Internet, but they need to have a say in the formulation of rules, laws and policies relating to ICTs, so that tools like the Internet can flourish as both a public good and a public space. Processes like the World Summit on the Information Society (WSIS), and the discussions around Internet governance and financing mechanisms (including things like the proposed creation of a Digital Solidarity Fund for Africa) are therefore vitally important' (Lannon 2005: 128-129).

In this respect, two issues are mentioned: 'commercialisation, integration, and concentration of ownership of the media'; and 'international laws regarding intellectual property that have attempted to reinforce the domination of Northern countries and their corporate allies.' Social and solidarity movements can work on these issues. 


\section{Concluding remark}

The analysis of the Yogyakarta Commemoration Group as a social movement enables us to identify its characteristics, its prospect, and its project.

\section{Characteristics}

Its characteristics can be summarised as follows.

Identity. Its identity can be seen from the basic reference of the event it organised: the Bandung Spirit as described in the introduction of this article. The composition of the people involved in the commemoration is interesting to note. Seen from the point of view of 'geopolitical' representation, the composition is complicated. There are authors who belong to the Asian nationality but are living in Europe (Darwis Khudori, Indonesian living in France) or the inverse (Hersri Setiawan, Dutch living in Indonesia; Jean-Pascal Bassino, French living in Japan). There are authors belonging to two nationalities such as Patricia Morales (Argentina/Netherlands) and Boutros Labaki (Lebanon/Italy). If the country of origin of the authors is taken as the criterion, the proportion of Western and Non-Western representation is six (Finland, France, Germany, Ireland) and ten (Argentina, Cameroon/Senegal, India, Indonesia, Japan, Lebanon, Thailand). While the North and South representation is seven (Finland, France, Germany, Ireland, Japan) and nine (Argentina, Cameroon/Senegal, India, Indonesia, Lebanon, Thailand).

Seen from the point of view of the socioprofessional category, the group is composed of two profiles: academics and activists, with a large proportion of the first (Bernadette Andreosso-O'Callaghan, Bernard Founou-Tshuigoua, Boutros Labaki, Darwis Khudori, Jean-Pascal Bassino, John Lannon, Kaarina Kailo, Majid Tehranian, Nirmal Kumar Chandra, Parichart Suwanbubbha, Patricia Morales) compared to the second (Hersri Setiawan, Pierre Rousset, Wolfgang R. Schmidt, Yukio
Kamino). It has to be noticed, however, that most of the authors have a double profile: academics who participate actively in associative movements and activists who have an academic background.

In any case, the composition of the authors represents perfectly the universality and the specificity of the Group. It is universal in the sense that it corresponds to the present trend of social and solidarity movements characterised by the transnational composition of the group, combining people from the North as well as from the South, from the Western as well as from the Non Western World, from the academic world as well as from associative movements. It is specific in the sense that the leading actors and the majority of the actors are from the South and from the Non-Western World.

Opposition. The Group opposes the present state of the World Order and the present course of Globalisation, especially related to the domination of the powerful upon the rest of the world. Some authors identify clearly their 'enemy': the US and their allies (the Western/Northern/Industrialised/ Developed/Rich countries, World Bank, IMF, ...), but in general the authors point out the 'system' instead of the 'actors' of domination.

Totality. It proposes alternatives to the present World Order and Globalisation at diverse levels (long term, middle term, short term) and areas (Politics, Economics, Culture, Environment, Education, Communication) in the form of Goals and Issues as the basis of its collective work.

Prospect. The prospect of this movement will depend on two factors: internal and external ones.

Internal factor. It depends on the willingness of the Group to continue to exist, to be faithful to its basic reference, to maintain and/or strengthen its cohesion, and to work on the Goals and Issues it defined. It means also 
that it depends on its capacity to regenerate, renew, perpetuate itself, especially with new generations of academics and activists willing to join in the movement.

At present, this group constitutes an interesting profile in the landscape of social and solidarity movements in the world, as stated in the characteristics above, especially for the fact that the leading and majority of the actors are from the South and from the Non-Western World, which still suffer the domination of the powerful, and that they form a coalition of influential academics, activists and religious leaders. The problem is that many of them are officially at the age of retirement (Samir Amin, François Houtard, Hersri Setiawan, Yves Berthelot, Boutros Labaki, Bernard Founou Tchuigoua, Nirmal Kumar Chandra, Wolfgang R. Schmidt). Therefore, regeneration is a crucial question for the continuity of the group.

External factor. The prospect of the Group depends on the relevance of its basic reference and its concrete work for the world situation, especially in proposing alternatives to the situation it criticises. At present, its basic reference (Bandung Spirit) is highly relevant to the challenge of the World Order and Globalisation, as evoked by some of the essays of the book. Seen from the complexity of the world problems it identifies, it is clear that its basic reference will still be relevant for a long time, if not forever. As for its concrete work, it is still to be seen, because it has just started to work.

Project. The Yogyakarta Commemoration Group has proposed the necessary elements of a social project in a global perspective through a set of fundamental goals and a considerable number of issues. It has to be noticed, however, that all the goals and issues proposed by the authors do not represent a collective work. They represent individual views of the authors, which have not been elaborated or approved collectively as a project proposal. They have formed nevertheless a good base for a project proposal, although there are some gaps. In terms of
Areas (of work), for example, some authors evoke the issue of the use of social sciences for the interest of the powerful. This issue is not covered by any area. Therefore, it may be worth adding Science and Technology to the list of Areas. There are also pressing issues related to the basic needs for living that are not evoked in the book, such as the commercialisation of water, the spread of AIDS, the increasing scarcity of the sources of energy. These issues may be grouped into another new area, for example Basic Needs. On the other hand, there are areas that are not sufficiently filled in with issues. This concerns, for example, the areas of the Environment, Education and Communication, each of which is represented only by one author. There are pressing issues that are not mentioned or developed in those areas, such as deforestation (Environment), commercialisation of education (Education), the use of media for the interest of the powerful (Communication). These lacks are understandable, since the publication was intended to be a 'preliminary work' for a greater event supposed to be organised later. So, they can be completed in the following activities. The question is what kind of event or activities can be developed from the 'preliminary work'? What will be the basis of the movement? What will be its relationship with other types of civil society movements? What will be its position related to the states or governments?

The keywords of the 'preliminary work' were 'Rethinking' (Solidarity in Global Society) and the 'Challenge' (of Globalisation for Social and Solidarity Movements). Therefore, it seems logical that the next activities or event, if there will be any, would be oriented towards the consequences of the 'rethinking' as a 'response' to the 'challenge'. It is clear from the diverse goals and issues proposed in the book that the Group needs to develop not only 'reflections', but also 'actions'. The Group cannot work only at the level of 'discourses' for an 'abstract' society, but also and especially 'actions' in the middle of a 'concrete' community. In order to achieve its 'global' goals, the Group needs a 'local' basis for its 
actions. For that respect, some essays have given a clear indication and justification: theoretically, Regionalism can be an effective way to change the present course of Globalisation; concretely, Africa and Asia are the region that corresponds perfectly to the profile of the Group for several reasons. The most important one is that Africa and Asia share many things in common, especially the suffering from the domination by the powerful, the Colonisation in the past, and the Globalisation today. It is also in Africa and Asia that we find the poorest and least developed countries in the world. Above all, Africa and Asia are the basis of the movements started in the Bandung Asian-African Conference 1955. By taking Africa and Asia as the basis of the movement, it does not mean that the Group is closed to people or organisations based outside Africa and Asia. It means that the leading actors of the Movement are based in, or citizens of, African or Asian countries and that the basic field of their work is Africa and Asia. People or organisations based outside Africa or Asia can join in the Movement as allies.

In this case, the Yogyakarta Group cannot neglect the result of the AsianAfrican Summit - organised by the governments of Asian and African countries in the framework of the commemoration of the 50th anniversary of the Bandung AsianAfrican Conference - in Jakarta and Bandung in April 2005. The result cannot be neglected, because the states of Africa and Asia are also the legitimate heirs of the Bandung Asian-African Conference and their project is something to do with the Bandung Spirit. The theme of their summit was 'Reinvigorating the Bandung Spirit: Working Towards a New Asian-African Strategic Partnership' known as NAASP (http://www.asianafricansummit2005.org /default.htm). Among the most relevant points proposed by the summit, related to the question of Civil Society Organisations, is the following declaration:

We resolve that the sustainability of the NAASP shall be conducted through three tiers of interaction: an intergovernmental forum; sub-regional organizations; and people-to-people interaction, particularly business, academia, and civil society. follows:

They have also set up an agenda as

We are determined to develop an institutionalized process of the NAASP through convening: a Summit of Heads of State/Government every four years; a Ministerial Meeting of Foreign Ministers every two years; and Sectoral Ministerial and other Technical Meetings when deemed necessary. A Business Summit in conjunction with the Summit of Heads of State/Government will be held every four years. (http:// www.asianafricansummit2005.org/ statements_declaration.htm)

It is interesting to notice that the Final Declaration has included an agenda for the Business Summit, but not for the Civil Society Summit. This fact may give advantage and disadvantage to Civil Society Movements. Advantage, because Civil Society is not the affair of government. It is the duty of the Civil Society Movements to decide what they should do. It may mean that the activists of Civil Society Organisations in Africa and Asia can develop their projects freely, without the control of the states. Disadvantage, because it may mean that the governments do not take into consideration seriously the Civil Society Movements; that the mention of Civil Society in the Final Declaration is just a kind of 'lip service' in order to appear 'politically correct'; and that the attitude of the governments will be indifferent when the Civil Society Movements take the same line of the governmental policy but repressive when the Civil Society Movements take a critical position. It may mean also that there will be no moral support, let alone financial support, from the states to the Civil Society Movements.

The Yogyakarta Group can take into consideration this situation in its project proposal without losing its principle: keeping independent position and critical attitude vis-à-vis the states. 


\section{Notes}

1. Castells explains this notion by using other words: identity means the self-definition of the movement, what the movement is, in the name of whom the movement speaks; opponent - the principle of opposition - is the main enemy of the movement, which the movement designates consciously as such; societal objective - the principle of totality - is the idea which the movement has on the type of social order, or social organisation, to which the movement wishes to lead toward a historical horizon of its collective action (Castells 1997).

2. Hersri Setiawan is a writer, journalist and activist of social and cultural organisations, and a former representative of the Indonesian National Committee for the Asian-African Writers' Bureau in Colombo (1961-1965).

3. Bernadette Andreosso- $\mathrm{O}^{\prime}$ Callaghan is an Ireland-based French, economist, Jean Monnet Professor of Economics and director of the EuroAsia Centre, the University of Limerick, Ireland.

4. Jean-Pascal Bassino is French, an economist, and associate professor at Paul Valery University, Montpellier, France, temporarily based in Japan.

5. Kaarina Kailo is Finnish, a scholar of Women Studies, and a former professor of Women's Studies and Multiculturalism at Oulou University, Finland, currently more active in municipal politics and the international prodemocracy network, women's and peace organisations (Feminists for a Gift Economy, FemAttac).

6. Nirmal Kumar Chandra is Indian, an economist, a retired professor of Economics, Indian Institute of Management, Calcutta, and a member of the Third World Association of Economists.

7. Yves Berthelot is French, and economist, a former Deputy Secretary General of UNCTAD, a former Executive Secretary of Economic Commission for Europe, and president of the Centre International Lebret-IRFED - a France/ Switzerland-based NGO dedicated to dialogue and development.

8. Yukio Kamino is Japanese, a scholar of Social Sciences, with a background in African and Asian Studies. Kamino is an environmental activist, Co-Chair of the International Coordination Committee, OISCA International - a Japan-based transnational NGO dedicated to environmentally sustainable development worldwide.

9. Majid Tehranian is American/Iranian, a professor of International Communication at the University of Hawaii, and director of the Toda Institute for Global Peace and Policy Research.

10. Wolfgang R. Schmidt is German, a theologian, a scholar of International Law and Political
Science, and a former executive secretary of the World Council of Churches (WCC, Geneva, Switzerland). He is currently president of the World-wide Ecumenical Partnership, Germany / Switzerland.

11. Patricia Morales is Argentinean/Dutch, a painter, writer, philosopher, and associate researcher at the Globus Institute for Globalisation, University of Tilburg, the Netherlands, and Catholic University of Leuven, Belgium, especially on the question of peace and solidarity in Latin American countries.

12. Pierre Rousset is French, the president of ESSF (Europe Solidaire Sans Frontières), a member of the International Commission of ATTAC (Association pour la Taxation des Transactions financières pour l'Aide aux Citoyens) for Asia-Pacific Link, and adviser to the European United Left/ Nordic Green Left Group in the European Parliament.

13. Bernard Founou-Tchuigoua is Cameroonese/ Senegalese, an economist, a former professor of Economics at Algiers University (Algeria) and IDEP (African Institute for Development and Planning), Dakar (Senegal), and research director at the Third World Forum, Dakar, Senegal.

14. Darwis Khudori is a France-based Indonesian, and coordinator of the International Organising Committee of the Yogyakarta Commemoration of the 50th anniversary of Bandung Asian-African Conference. See his short biography at the end of this article.

15. Boutros Labaki is Lebanese/Italian, a development economist, an engineer, activist and professor of Economic Development, Economic History and Sociology of the Middle East and the Arab World at Lebanese University, American University and Saint Joseph University in Beirut. Labaki is also Senior Vice-President of the Council of Reconstruction and Development of Lebanon (1991-2000), General Secretary of ILDES (Institut libanais pour le développement économique et social, Lebanon) and Vice President of the Centre International Lebret-IRFED (France/Switzerland) for Middle East and Arab World Research, Director at St Joseph University (Beirut).

16. Parichart Suwanbubbha is Thai, a scholar of Education Science and Religious Studies, an assistant professor of Religious Studies, and chairperson of Comparative Religion Graduate Programme at Mahidol University, Salaya, Nakornpathom, Thailand. Suwanbubbha is also a member of the working committee of Mahidol University Research Center for Peace Building.

17. John Lannon is Irish, a software design/development engineer, a scholar of Peace and Development Studies, Human Rights activist, and a 
researcher with the Praxis Centre for the study of Information and Technology in Peace, Conflict Resolution and Human Rights at Leeds Metropolitan University (UK). He is also a lecturer at the Euro-Asia Centre, University of Limerick, Ireland.

\section{References}

Afro-Asian Peoples Solidarity Organisation (AAPSO) (2005) 'The resume of the International Conference on "Vision of Bandung after 50 years in Facing New Challenges" held in Cairo March 1-3, 2005, at Pyramisa hotel'. In Darwis Khudori (ed.) BANDUNG 2005: Rethinking Solidarity in Global Society. The Challenge of Globalisation for Social and Solidarity Movements, Yogyakarta: Department of Anthropology, Faculty of Cultural Sciences, Gadjah Mada University, and Yayasan Pondok Rakyat.

All India Peace and Solidarity Organisation (AIPSO) (2005) 'We Owe a Lot to Bandung'. In Darwis Khudori (ed.) BANDUNG 2005: Rethinking Solidarity in Global Society. The Challenge of Globalisation for Social and Solidarity Movements, Yogyakarta: Department of Anthropology, Faculty of Cultural Sciences, Gadjah Mada University, and Yayasan Pondok Rakyat.

Andreosso-O'Callaghan, Bernadette and JeanPascal, Bassino (2005) 'Socio-economic Convergence in the Bandung Countries, 1960-1999'. In Darwis Khudori (ed.) BANDUNG 2005: Rethinking Solidarity in Global Society. The Challenge of Globalisation for Social and Solidarity Movements, Yogyakarta: Department of Anthropology, Faculty of Cultural Sciences, Gadjah Mada University, and Yayasan Pondok Rakyat.

Berthelot, Yves (2005) 'Bandung Fifty Years Later: Toward Another Development Model for the Post Globalisation Era'. In Darwis Khudori (ed.) BANDUNG 2005: Rethinking Solidarity in Global Society. The Challenge of Globalisation for Social and Solidarity Movements, Yogyakarta: Department of Anthropology, Faculty of Cultural Sciences, Gadjah Mada University, and Yayasan Pondok Rakyat.

Castells, Manuel (1997) The Power of Identity, Oxford: Blackwell Publishers.

Chandra, Nirmal Kumar (2005) 'Economics of Bandung - Then and Now'. In Darwis Khudori (ed.) BANDUNG 2005: Rethinking Solidarity in Global Society. The Challenge of Globalisation for Social and Solidarity Movements, Yogyakarta: Department of Anthropology, Faculty of Cultural Sciences, Gadjah Mada University, and Yayasan Pondok Rakyat.
Founou-Tchuigoua, Bernard (2005) 'Solidarity Among the Peoples of Africa and Asia: Elements of A Political Economy'. In Darwis Khudori (ed.) BANDUNG 2005: Rethinking Solidarity in Global Society. The Challenge of Globalisation for Social and Solidarity Movements, Yogyakarta: Department of Anthropology, Faculty of Cultural Sciences, Gadjah Mada University, and Yayasan Pondok Rakyat.

Kailo, Kaarina (2005) 'Solidarity and Globalism Revisited: The Gift Imaginary and New Models of the Human'. In Darwis Khudori (ed.) BANDUNG 2005: Rethinking Solidarity in Global Society. The Challenge of Globalisation for Social and Solidarity Movements, Yogyakarta: Department of Anthropology, Faculty of Cultural Sciences, Gadjah Mada University, and Yayasan Pondok Rakyat.

Kamino, Yukio (2005) 'Time for a Change of Heart: Facing the Global Environmental Crisis'. In Darwis Khudori (ed.) BANDUNG 2005: Rethinking Solidarity in Global Society. The Challenge of Globalisation for Social and Solidarity Movements, Yogyakarta: Department of Anthropology, Faculty of Cultural Sciences, Gadjah Mada University, and Yayasan Pondok Rakyat.

Khudori, Darwis (2005) 'Identity-based Social Movements facing Globalisation: Challenge and Response, Resistance and Alternative'. In Darwis Khudori (ed.) BANDUNG 2005: Rethinking Solidarity in Global Society. The Challenge of Globalisation for Social and Solidarity Movements, Yogyakarta: Department of Anthropology, Faculty of Cultural Sciences, Gadjah Mada University, and Yayasan Pondok Rakyat.

Labaki, Boutros (2005) 'Interrelated Solidarity Links in a Global Society: Islamic-Christian Dialogue and South-North Relations'. In Darwis Khudori (ed.) BANDUNG 2005: Rethinking Solidarity in Global Society. The Challenge of Globalisation for Social and Solidarity Movements, Yogyakarta: Department of Anthropology, Faculty of Cultural Sciences, Gadjah Mada University, and Yayasan Pondok Rakyat.

Lannon, John (2005) 'Information and Communication Technologies: New Global Challenges and Opportunities for Social and Solidarity Movements'. In Darwis Khudori (ed.) BANDUNG 2005: Rethinking Solidarity in Global Society. The Challenge of Globalisation for Social and Solidarity Movements, Yogyakarta: Department of Anthropology, Faculty of Cultural Sciences, Gadjah Mada University, and Yayasan Pondok Rakyat.

Morales, M.C. Patricia (2005) 'A Latin American Approach to Solidarity'. In Darwis Khudori (ed.) BANDUNG 2005: Rethinking Solidarity in Global Society. The Challenge of Globalisation for Social and Solidarity Movements, Yogyakarta: 
Department of Anthropology, Faculty of Cultural Sciences, Gadjah Mada University, and Yayasan Pondok Rakyat.

Rousset, Pierre (2005) 'The World Social Forum: A New Framework for Solidarities'. In Darwis Khudori (ed.) BANDUNG 2005: Rethinking Solidarity in Global Society. The Challenge of Globalisation for Social and Solidarity Movements, Yogyakarta: Department of Anthropology, Faculty of Cultural Sciences, Gadjah Mada University, and Yayasan Pondok Rakyat.

Setiawan, Hersri (2005) 'Learning from History: "The Bandung Spirit"'. In Darwis Khudori (ed.) BANDUNG 2005: Rethinking Solidarity in Global Society. The Challenge of Globalisation for Social and Solidarity Movements, Yogyakarta: Department of Anthropology, Faculty of Cultural Sciences, Gadjah Mada University, and Yayasan Pondok Rakyat.

Suwanbubbha, Parichart (2005) 'Bandung 2005 and Educational Challenges in the Age of Globalisation'. In Darwis Khudori (ed.) BANDUNG 2005: Rethinking Solidarity in Global Society. The Challenge of Globalisation for Social and Solidarity Movements, Yogyakarta: Department of Anthropology, Faculty of Cultural Sciences, Gadjah Mada University, and Yayasan Pondok Rakyat.

Tehranian, Majid and Schmidt, Wolfgang R. (2005) 'Proposals for Global Solidarity in a Plural
World'. In Darwis Khudori (ed.) BANDUNG 2005: Rethinking Solidarity in Global Society. The Challenge of Globalisation for Social and Solidarity Movements, Yogyakarta: Department of Anthropology, Faculty of Cultural Sciences, Gadjah Mada University, and Yayasan Pondok Rakyat.

\section{Author's biography}

Darwis Khudori is a writer (poems, short stories, essays), an engineer-architect (Gadjah Mada University, Yogyakarta, Indonesia, 1984; Institute for Housing and Urban Development Studies, Rotterdam, the Netherlands, 1987 and 1989), and historian (doctorate in History of Contemporary Arab and Muslim World, University of Paris-Sorbonne, France, 1999). Director of Master's Degree in International Affairs, specialising in Trade with Asia, at the Faculty of International Affairs, University of Le Havre, France (www.univ-lehavre.fr), he is also a Board Member of Yayasan Pondok Rakyat (People's Shelter Foundation), Yogyakarta, Indonesia (www.ypr.or.id), and Centre International Lebret-IRFED, Paris/Geneva, France/Switzerland (www.lebret-irfed.org).

Contact address: Faculty of International Affairs University of Le Havre 25, rue Philippe Lebon, BP 420 Le Havre 76057 Cedex, France 